\title{
EMPLOYERS' LIABILITY IN GREAT BRITAIN
}

\author{
W. F. Frank* \\ I \\ Employers' Liability at Common Law
}

A. The Employer's Duties concerning the Safety of his Servants

"The law of employer's liability is concerned with the liability of an employer to pay damages to his servants for injuries which they have sustained in the course of their work."

The purpose of this paper is to give a summary of the law in Great Britain ${ }^{2}$ as it has developed over the last twenty-five years. The inclusion of the National Insurance (Industrial Injuries) Act, $1946{ }^{3}$ though unjustified on the basis of the above definition, may be explained historically since it has taken the place of the earlier workmen's compensation scheme.

The common law liability of an employer for injuries suffered by his servants may be discussed under three headings-namely, liability for his own negligence, vicarious liability for the negligence of other employees, and liability for the breach of some duty imposed on him by statute.

Negligence has been defined in the well-known words of Alderson, B., as ... the omission to do something which a reasonable man, guided upon those considerations which ordinarily regulate the conduct of human affairs, would do, or doing something which a prudent and reasonable, man would not do.

What a reasonable employer would do in order to safeguard the health and bodily integrity of his employees is a question of fact, but as a result of a series of decisions the broad outlines of the employer's duties have now become well defined. Singleton, L. J., has summed up the position. in a recent case as follows: ${ }^{5}$

The duty of the employer is to act reasonably towards his men; to take care, in the way that a prudent employer would, to see that his workmen are not exposed to unnecessary risks; and that obligation extends to the building in which they work, to the plant, and in some cases at least it covers the providing of a proper system of work.

In the light of this statement the employer's duties may be detailed thus.

I. The duty to provide a reasonably safe place of work. The employer is not

* Dr.jur., M.Sc. (Econ.), B.Com., LL.B. Senior Lecturer in legal and economic studies at Derby Technical College. Editor of the Industrial Law Review and the Industrial Information Service. Author, THE New Industrial Law (I950), and of articles on legal and economic topics.

1 John H. Munkman, EMpioyers' Liability at Common Law i (I950).

2 As far as the common law is concerned, the position described is that prevailing in England, i.e., no reference is made to Scots law.

${ }^{3} 9$ \& I0 Geo. 6 , c. 62 .

4 Blyth v. Birmingham Waterworks Co., II Ex. 781, 784, 156 Eng. Rep. 1047, 1049 (1856).

'Latimer v. A. E. C., Ltd., [1952] I T. L. R. 1349, 1353. 
absolutely liable for the safety of the building or other place where work is carried on. He has to take reasonable care only to see the building is safe, which means among other things that the walls are safe, ${ }^{6}$ that the roof is safe, ${ }^{7}$ that the floors are not unduly slippery, ${ }^{8}$ and that there is proper ventilation ${ }^{9}$ and insulation. ${ }^{10}$ The employer must take reasonable care to assure that no danger is allowed to continue of which he is aware or ought to be aware. ${ }^{11}$ Where the defect is a hidden one, it is a question of fact whether the employer should have been aware of it. If the employer knows of a danger and makes some provision to guard his servants against it, it is again a question of fact whether he has done all that might be reasonably expected of a prudent employer in the circumstances. In brief, there are no absolute standards of safety at common law: everything depends on the facts of the case.

2. The duty to provide reasonably safe plant, machinery, and materials. The employer's liability in this respect is similar to that for the safety of the building. Again, he has only to do what could be reasonably expected of a prudent employer. This necessitates periodical inspection of plant and machinery and the repair or replacement of such items as have been found to be defective and potentially dangerous. A fortiori this has to be done where the employer has been warned about the dangerous nature of some piece of equipment. The employer is also in breach of his duty if he altogether fails to provide the necessary equipment. If the servant himself selects some piece of equipment which proves to be defective, not having been provided with suitable equipment by the employer, the employer will be liable. ${ }^{12}$ Where the employer has provided suitable equipment, but the servant fails to use it, the employer will, of course, not be liable to him for any injury he might have suffered because of it.

3. The duty to provide a reasonably safe system of work. This is a kind of allembracing duty, making the employer responsible for injuries caused by negligence not connected with the tangible means of production. In the leading case of Wilsons and Clyde Coal Co. Ltd. v. English, ${ }^{13}$ a miner, who was about to leave the pit after having completed his shift, was crushed to death when the haulage plant was suddenly and without warning put into operation. The House of Lords held the

\footnotetext{
- Brydon v. Stewart, 2 Macq. 30 (H. L. 1855 ).

7 Paterson v. Wallace, I Macq. 748 (H. L. $x 854$ ).

${ }^{8}$ Davidson v. Handley' Page, Ltd., [I945] I All E. R. 235 (C. A.), but see also Latimer v. A. E. C., Ltd., note 5 stupra.

${ }^{\circ}$ Wilson v. Merry, L. R. I Sc. \& Div. App. 326 (1868).

${ }^{10}$ Paine v. Colne Valley Electricity Supply Co., Ltd., and British Insulated Cables, Itd., [1938] 4 All. E. R. 803.

${ }^{11}$ From this follows also that where the employee works in a place which is not under his employer's control, the employer, not being of course aware of any defects in the structure etc., will not be liable if the place is not reasonably safe. The recent decision of the Court of Appeal in Christmas v. General Clcaning Contractors, [1952] I All E. R. 39, seems to indicate, however, that an employer who sends his workmen to other people's premises must take reasonable care that these premises are safe or take proper steps to protect his employees from such dangers as they are likely to face. This decision has now been affirmed by the House of Lords, [1953] 2 W. L. R. 6.

${ }_{12}$ Lovell v. Blundells and Crompton \& Co., Ltd., [1944] I K. B. 502.

${ }^{13}$ [1938] A. C. 57.
} 
colliery company liable on the ground that their system of work was not reasonably safe.

The system of work must not be confused with the methods adopted by individual servants; it includes "the physical lay-out of the job ... the sequence in which the work is to be carried out, the provision in proper cases of warnings and notices, and the issue of special instructions."14 Under this heading we may also include the duty to give reasonably adequate instruction to untrained staff, ${ }^{10}$ the general co-ordination of separate departments, ${ }^{16}$ and the adequate lighting of all parts of the building. ${ }^{17}$

\section{B. Vicarious Liability}

If this article had been written some five years ago, vicarious liability would have played but an insignificant part in our subject. Under the doctrine of common employment, the employer was not liable to a servant who had been injured through the negligent act of a fellow-servant who was in common employment with him. Section I(r) of the Law Reform (Personal Injuries) Act, $1948,{ }^{18}$ abolished this doctrine. This development has substantially increased the scope of employers' liability. Vicarious liability for the acts of one's servants is now too well established to demand justification, ${ }^{19}$ but the master is, of course, only liable if the servant causing the injury has been acting in the course of his employment.

Although the doctrine of common employment has been abolished the fact of servants being in common employment is still of some importance. Mr. Munkman maintains that in such cases fellow-servants owe a special duty of care to each other and that the employer is liable for any breach of this duty. ${ }^{20}$ Further, while an employee may contractually surrender his right of action against his employer for the latter's personal negligence, such a contract would be void in so far as it tended to exclude the employer's vicarious liability for his servants' negligence. ${ }^{21}$

\section{Breach of statutory duty}

In an action for damages on the ground of common law negligence the employer is in no different position from any other defendant. Whether or not he has been guilty of negligence is a question of fact, depending on a comparison of his behavior with that of a hypothetical prudent employer in the same set of circumstances. His position in an action for breach of a statutory duty is a different one. The duties of the employer are here fixed by statute and do not depend on

${ }^{1 *}$ Per Lord Greene, M. R., in Speed v. Thomas Swift \& Co., Ltd., [1943] K. B. 557, 563.

${ }^{15}$ Cribb v. Kynoch, Ltd., [1907] 2 K. B. 548.

${ }^{16}$ Dyer v. The Southern Railway, [1948] I K. B. 608; see also Wilsons and Clyde Coal Co., Ltd. v. English, supra note 13 .

${ }^{17}$ Garcia v. Harland \& Wolf, Ltd., [1943] I K. B. 73 I.

${ }^{18}$ II \& 12 Geo. 6, c. 4 T. See section $E(\mathrm{I})$ infra.

${ }^{19}$ For a strong attack on the principle of vicarious liability, consult Thomas Batx, Vicarrous LiabizITY (Igr6). tion.

${ }^{20}$ See Munxaran, op. cit. supra note $\mathrm{I}$, at 58 . There is so far no judicial support for this proposi-

${ }^{2 x}$ Sec. I(3) of the Law Reform (Personal Injuries) Act, I948. Smith v. B. E. A. C., [195I] 2 T. L. R. 608 , applies this principle to a pension scheme introduced by the employers. 
the opinions of a jury as to what constitutes reasonable conduct. For a long time it was doubtful whether an action for damages would lie at all where an act either provided no special remedies or contained criminal sanctions only. Since Groves $v$. Wimborne $e^{22}$ the matter is considered as settled by reference to the general purpose of the act of Parliament concerned. If it may be said that the act has been passed for the protection of a certain class of persons, then any member of that class may bring an action for damages if he has suffered a loss because of a breach of a duty imposed by the act.

It is generally stated that statutory duties are absolute ones. This means that the person on whom the duty is imposed cannot delegate the duty; he will remain responsible even though he has instructed someone else to perform whatever may be necessary. It further means, however, that if a statute imposes a duty on an employer, the employer is bound to observe it whether or not it may be reasonable or practicable. ${ }^{23}$ The practical implications of this far-reaching doctrine have been to some extent affected by re-introducing the test of reasonableness through the backdoor. While the duties imposed by statute may be absolute ones, it still remains to be settled in each case whether the duty has come into existence. If, for instance, a statute provides that all dangerous machinery should be securely fenced, ${ }^{24}$ when is a machine dangerous? In a much-quoted judgment, du Parcq, J., said: ${ }^{25}$

In considering whether machinery is dangerous it must not be assumed that everybody will always be careful. . . a a part of machinery is dangerous if it is a possible cause of injury to anybody acting in a way in which a human being may be reasonably expected to act in circumstances which may be reasonably expected to occur.

This test of reasonable foreseeability has now been generally accepted by the courts.

The questions as to whether (a) there exists a duty (e.g., to fence a dangerous machine) and (b) whether this duty has been discharged (i.e., the machine has been securely fenced) are of course separate ones, but it appears that the issues involved are often confused. ${ }^{26}$

Where a duty is imposed by statute with a view to protecting certain persons, only these persons may bring an action for damages and the injury for which the action is brought must be the one which the statute was trying to avoid when placing an obligation on the employer. ${ }^{27}$

$2 \approx$ [ 1898$] 2$ Q. B. 402 .

23 "If a machine cannot be securely fenced while remaining commercially practicable or mechanically useful the statute in effect prohibits its use." Per Salter, J., in Davies v. Thomas Owen \& Co., Ltd., [1919] 2 K. B. 39 , 4I. No single standard of care is laid down in the Factories Act. Certain things have to be done by the employer absolutely, irrespectively of whether or not they are practicable (e.g., $\$ 14(1)$ fencing of dangerous parts of machinery). Other things have to be done if they are "practicable" (c.g., $\$ 47$ (I) removal of dust) or even "reasonably practicable" ( $\$ 26(\mathrm{I})$ provision of a safe means of access to every working place). The difference between these standards of care has been carefully analyzed by Parker, J., in Adsett v. K. \& L. Steelfounders and Engineers, Ltd., [1953] I W. I. R. I37.

${ }^{24}$ Sec. I4, Factories Act, 1937, I EDw. 8 and I GEo. 6, c. 67.

26 Walker v. Blctchley Flettons, Ltd., [1937] I All E. R. 170, 175.

so Note the dissenting judgment of Denning, L. J., in Burns v. Joseph Terry \& Sons, Ltd., [195I] I T. L. R. 349,356 .

37 "Fencing . . means the erection of a barricade to prevent any employee from making contract 


\section{Fatal accidents}

Where a servant has been killed in the course of his employment and negligence of the employer can be proved, whether at common law or under a statute, the servant's dependents may bring an action for damages. ${ }^{28}$ One action only may be brought on behalf of all of them and it will not succeed unless the deceased could have succeeded had he sued himself. The action is one for damages for the financial loss which the dependents have suffered by the death of the deceased and they have to bring into account all financial benefits accruing to them in consequence of the death. ${ }^{29}$

Since 1934 another common law principle (actio personalis moritur cum persona) has also been partially abolished. ${ }^{30}$ Prior to 1934 any rights to damages for personal injury belonging to an injured person were extinguished when he died. The gist of the 1934 Act is that these rights are now treated as part of his estate and may be enforced by his personal representatives. As the widow of the deceased workman will usually be the administratrix of his estate, we find that she frequently brings two actions against her husband's employers, one on her own behalf as widow and as guardian of any infant children the deceased may have left for the financial loss which she and the children have suffered, and the other as the administratrix (or executrix) of her husband's estate for such damages as he could have claimed had he not died. ${ }^{31}$ Where the dependents benefit by the distribution of the deceased's estate, the benefits received will be taken into account when assessing the amount of damages under the Fatal Accidents Acts. ${ }^{32}$

\section{E. The employer's defences}

Three defences used to be open to an employer in an action against him for damages brought by an injured workman or his dependents.

x. Common Employment. The history of the doctrine of common employment is too well known to warrant repetition here. Suffice it to say that even before the doctrine had been abolished in 1948 , judicial interpretation had already removed much of its sting. At first the doctrine seemed to claim that an employee when entering employment had impliedly contracted to take upon himself the risk of injury through some misconduct of his fellow-employees. Later decisions showed, however, that common employment meant more than employment by the same

with the machine, not an enclosure to prevent broken machinery from flying out." Carroll v, Andrew Barclay \& Sons, Ltd., [1948] A. C. 477, 486, per Lord Porter. Note also the decision of the House of Lords in Nicholls v. Austin (Leyton) Ltd., [x946] A. C. 493, and Dickson v. Flack, [1953] I W. L. R. 196.

${ }_{28}^{28}$ The Fatal Accidents Acts, $1846-1864$ (9 \& I0 VICT. c. 93, and 27 \& 28 Vicr. c. 95) had created this right by abrogating to that extent the common law principle that no action could arise out of the death of a human being. The dependents who may bring this action are husband and wife, parents, and children, in so far as they were actually dependent on the deceased.

${ }^{20}$ Money receivable under an insurance policy is disregarded (Fatal Accidents (Damages) Act, 1908, 8 EDw. 7 , c. 7). The same applies now also to benefits under the National Insurance Acts (Law Reform (Personal Injuries) Act $1948, \$ 2(5))$.

${ }^{30}$ Law Reform (Miscellaneous Provisions) Act, 1934, 24 \& 25 Geo. 5, c. 41 and $\$ 1$.

${ }^{31}$ E.g., for loss of expectation of life and for pain and suffering.

32 Davies v. Powell Duffryn Associated Colleries, Ltd., [1942] A. C. 6or. 
employer. The two servants had to be in such a job-relationship that the safety of one depended directly on the carefulness of the other. Thus, where a servant was injured through the negligence of a fellow-servant in circumstances where the injury could have been caused by any member of the public, the doctrine was held not to apply. ${ }^{33}$ So unpopular had the doctrine become towards the end of its life that the courts were forced to invent artificial distinctions in order to avoid its application. ${ }^{34}$

The doctrine of common employment was never held to apply to breaches of statutory duty, ${ }^{35}$ nor in cases where the master himself had been negligent, whether in not providing a safe system of work, ${ }^{36}$ or in failing to employ safe fellow-workers, or in any other respect.

2. Volenti non fit injuria. Like the defence of common employment this defence has also been much curtailed in the last twenty-five years. It had reached its extreme limit in the third quarter of the last century, ${ }^{37}$ but today it is probably allowed only where there is a positive agreement waiving the right of action. ${ }^{38}$ The new attitude dates from Smith $v$. Baker $\&$ Sons, ${ }^{39}$ where the House of Lords approved the famous dictum of Bowen, L. J., in Thomas $v$. Quartermaine, namely, that "the maxim ... is not scienti non fit injuria, but volenti."40 Professor Williams has pointed out that this defence has failed in practically every modern case in which it has been pleaded. ${ }^{41}$ The leading case of Bowater v. Rowley Regis Corporation ${ }^{42}$ illustrates the modern tendency. A road-sweeper had been induced, against his protests, to take on his round a horse which he knew to be dangerous. He was injured when the horse ran away. Scott, L. J., in the Court of Appeal distinguished between a man who was specifically employed in a dangerous occupation and, of course, was paid accordingly and another man not employed in an inherently dangerous job. The latter would be deprived of his remedies against his employer only on cogent proof that he had knowingly undertaken some dangerous task realizing that he would be working at his own risk. Professor Williams distinguishes between the assumption of the physical risk and the assumption of the legal risk ${ }^{43}$ by the employee. Only if the plaintiff had accepted the legal risk, fully understanding its nature, will the defendant be able to escape responsibility. ${ }^{44}$ Volenti non fit injuria can never be pleaded as a defence in an action for damages based on breach of some statutory duty. ${ }^{45}$

${ }^{33}$ Radeliffe v. Ribble Motor Services, Ltd., [1938] I All E. R. 7I (coach driver killed on road through negligence of fellow-driver employed by the same company); Glasgow Corporation v. Neilson, [1947] 2 All E. R. 346 (bus conductress injured through the negligence of driver of another bus cmployed by the corporation).

34 Compare Neilson's case, supra, with the earlier decision in Graham v, Glasgow Corporation, [1947]

I All E. R. I, where the vehicles concerned were trams.

${ }^{35}$ Groves v. Wimborne, [1898] 2 Q.B. 402.

${ }^{30}$ Wilsons \& Clyde Coal Co. v. English, [1938] A. C. 57.

${ }^{37}$ Woodley y. The Metropolitan District Railway, 2 Ex. D. 384 (1877).

${ }^{38}$ Glanvilie L. Williams, Joint Torts and Contributory Negligence 296 (I95I).

${ }^{30}[189 \mathrm{I}]$ A. C. 325.

10 I8 Q. B. D. 685,696 (1887).

42 WILLIams, op. cit. supra note 38 , at 307-308. [1944] K. B. 476.

${ }^{4}$ l.e., the risk of not being able to claim damages. Williass, op. cit. stipra note 38 , at 307 .

* Id. at 3 Ir.

${ }^{60}$ Wheeler v. New Merton Board Mills, Ltd., [1933] 2 K. B. 669. 
3. Contributory Negligence. Before the passing of the Law Reform (Contributory Negligence) Act, $1945^{46}$ there did not really exist such a thing as contributory negligence. Where both the plaintiff and the defendant were to blame for an accident, it fell to the court to decide whose negligence was the predominating cause of the accident. The party thus selected was then held entirely responsible in law and the negligence of the other party was disregarded. The 1945 Act changed the position in that now where both parties are to blame for an accident, the loss is shared between them in proportion to their respective degrees of fault. The practical result of this new principle has been well put by Denning, L. J. in Davies v. Swan Motor Co. (Swansea) $\mathrm{Ltd}^{47}$ as follows:

... the practical effect of the Act is wider than its legal effect. Previously, in order to mitigate the harshness of the doctrine of contributory negligence, the courts in practice sought to select, from a number of competing causes, which was the cause-the effective or predominant cause-of the damage and to reject the rest. Now the Courts have regard to all the causes and apportion the damages accordingly.

For some time it was doubted whether the defence of contributory negligence could be pleaded in actions for breach of a strict (statutory) duty. The House of Lords decided this issue in the affirmative in Caswell v. Powell Duffryn Associated Collieries Ltd. $^{48}$ Of course, the courts will be chary of finding contributory negligence where the act of the plaintiff was the very thing which the imposition of a statutory duty on the defendant was designed to prevent. ${ }^{40}$ The servant is not guilty of contributory negligence if he fails to ask for a safety device not provided by the employer, ${ }^{50}$ but if such a device has been provided it would be negligence on the servant's part not to use it. ${ }^{51}$

Turning now to the standard of care that an employee should observe, Denning, L. J. had the following to say: $:^{52}$

Although contributory negligence does not depend on a duty of care, it does depend on foreseeability. Just as actionable negligence requires the foreseeability of harm to others, so contributory negligence requires the foreseeability of harm to oneself. A person is guilty of contributory negligence if he ought reasonably to have foreseen that, if he did not act as a reasonable, prudent man, he might hurt himself: and in his reckonings he must take into account the possibility of others being careless. ${ }^{53}$

\section{F. Costs}

Since the introduction of the Legal Aid Scheme $e^{54}$ in the autumn of 1950 most manual workers are able to receive legal aid either entirely without cost to themselves or on payment of a small contribution on their part. It cannot be said for

\footnotetext{
8 \& 9 Gro. 6 , c. 28 .

17 [1949] 2 K. B. 29x, 322.

${ }^{48}$ [1940] A. C. 152.
}

${ }^{10}$ Hutchinson v. London and North Eastern Railway, [1942] I K. B. $48 \mathrm{I}$.

${ }^{\text {so }}$ Finch v. Telegraph Construction and Maintenance Co., Ltd., [1949] I All E. R. 452.

${ }^{51}$ See $\$ I I 9(I)$ of the Factories Act, I937, and Norris v. Syndi Manufacturing Co., Ltd., [1952] I T. L. R. Where the workman has willfully broken a guard provided by the employer, the employer would not be liable at all.

${ }^{52}$ Jones v. Livox Quarries, Ltd., [1952] I T. L. R. 1377, 1383.

${ }^{53}$ See also Williams, op. cit. stipra note 38 , at 352 .

"For a description of the scheme, see ERIC SACHS, Legar AId (1952). 
certain that this has increased the volume of litigation as any application for legal aid is carefully scrutinized by the local Legal Aid Committee before the applicant is granted a legal aid certificate. On the whole, however, the position of the assisted plaintiff has been strengthened in that while he may not win, he at least cannot lose. The successful defendant will hardly ever be granted costs against the assisted plaintiff as the latter's financial position is taken into account by the court in making a decision as to costs. There are no separate statistics for actions by servants against their employers, but in the first year of the operation of the scheme $34^{\circ}$ individuals and corporations who were successful defendants in actions brought against them by assisted plaintiffs had to pay their own costs. It is not surprising that demands have been made for an amendment of the scheme ${ }^{55}$ so as to make the Legal Aid Fund responsible for the costs of non-assisted successful defendants. Nothing has been done about it so far. $^{58}$

II

\section{The Workmen's Compensation Acts, I897-I945}

\section{A. The legal provisions}

The main reason for the passing of the first Workmen's Compensation Act in $1897^{67}$ was the insufficiency of the common law remedies available to a workman injured at work. Common law remedies were, and are, based on negligence, but the burden of proving negligence rests on the workman. If he should be unable to prove negligence or if, in the event of a fatal accident, his dependents should be unable to explain the cause of the accident, an action at common law would fail. Furthermore, in 1897 our common law was still disgraced by the existence of the doctrine of common employment which seriously curtailed the worker's rights at common law. The worker could derive some assistance from the provisions of the Employers' Liability Act, $1880^{58}$ which rendered the defence of common employment inapplicable in a few cases, but the Act was not as effective as it had been intended to be, since "contracting out" was permitted; neither did it apply where the injured worker had acted outside the scope of his authority. From a financial point of view the 1880 Act was not satisfactory either as it limited the amount of damages that could be awarded to the worker to a maximum of three years' average wages or $£ 300$, whichever amount was the smaller. There existed thus a definite need for an entirely new approach to the problem, an approach which would have to abandon the common law principle of "no liability without fault."

The ${ }^{8} 8_{97}$ Act applied to certain specifically dangerous employments only, such as employment in factories, mines, quarries, railways, engineering works, and certain types of building undertakings. In $1900^{59}$ the workmen's compensation scheme was

Ev E.g., letter to the Editor of The (London) Times by Mr. Claud Mullins, May I7, 1952, p. 5 .

${ }^{60}$ It should also be noted that most trade unions give legal aid to their members in matters arising out of their employment.

${ }^{67} 60$ \& $6 \mathrm{I}$ VICT. c. 37 .

${ }^{58} 43$ \& 44 VICT. c. 42.

co Workmen's Compensation Act, r9oo. $63 \& 64$ Vict. c. 22. 
extended to cover also workers in agriculture and, finally, in $1906^{60}$ workers in any occupation were brought under the protection of the Acts. The existing legislation was consolidated in the Workmen's Compensation Act, $1925^{61}$ and this Act, subject to minor amendments, remained in existence until the abolition of the workmen's compensation scheme by the National Insurance (Industrial Injuries) Act, $1946^{62}$ In the present paper a description of the law as it stood on July 5, x948 is given and no further reference will be made to the purely historical aspects of the subject.

The essence of the Workmen's Compensation Act may be found in its first section which provided that

if in any employment ... personal injury by accident arising out of and in the course of the employment is caused to a workman, his employer shall ... be liable to pay compensation....

The apparent simplicity of this section is belied by the record. In the standard textbook on the Workmen's Compensation Act ${ }^{63}$ (itself a work of over 1200 pages of text) no less than 152 pages of close print are devoted to an explanation of this section alone.

The Act applied to "workmen," defined as persons working under a contract of service with an employer, irrespective of whether the work was manual or nonmanual. Non-manual workers earning more than $£_{350}$ p.a. ( $\oint_{420}$ p.a. as from January $I, 1942$ ) were excepted from the definition as were also casual workers not employed for the purposes of any trade or business, members of the police force, outworkers, and members of the employer's family dwelling in his house.

"Accident" was used in its common meaning, denoting in the words of Lord Macnaghten, ${ }^{64}$ "an unlooked-for mishap or an untoward event which is not expected or designed." The event had to be unexpected from the workman's point of view even though it was the result of the intentional act of another party. ${ }^{06}$ Industrial diseases raised some interesting problems. A disease which was the gradual result of work at some occupation (e.g., the miner's beat hand or beat knee, lead poisoning resulting from handling lead-containing substances) could not be said to have arisen by accident, since "accident" was always associated with some sudden, single occurrence which, so to say, transformed at once a healthy worker into an injured one. There are, of course, instances where it is possible to ascribe a disease to one particular event and in these cases the disease would be treated as a

${ }^{\circ}$ Workmen's Compensation Act, 1906. 6 Evw. 7, c. 58.

a1 15 \& 16 GEo. 5 , c. 84 .

029 \& 10 GEo. 6, c. 62. The Act came into operation on July 5, 1948.

${ }^{\circ} 3$ Willis, Workmen's CoMapensation (34th ed. I944).

os Fenton v. J. Thorley \& Co., Ltd., [1903] A. C. $443,448$.

${ }^{\circ E}$ E.g., the death of a teacher after an assault by some of the boys in his charge. Trim Joint District School v. Kelly, [19r4] A. C. 66\%. Self-inflicted injuries would, of course, not be treated as injuries by accident. Suicide, on the other hand, was treated as death by accident where it resulted from insanity consequent upon some personal injury suffered by accident (Dixon v. Sutton Heath Colliery No. 2,23 B. W. C. C. 135 (1930)). 
"personal injury by accident." treated as if they were personal injuries by accident provided the workman was certified by a certifying surgeon ${ }^{67}$ as suffering from a disease mentioned in the Third Schedule to the Act and was thereby disabled from earning full wages at his work. The Third Schedule to the Act contained a list of six diseases, but in pursuance of powers granted to him by the Act, the Home Secretary added by regulations further ones so that ultimately the list covered thirty-five diseases. Against each disease one or more processes were mentioned in which that disease most frequently occurred. If a workman had been immediately before the onset of the disease employed in one of the processes bracketed with it, a presumption in his favor was raised that the disease arose out of the employment and the burden of rebutting this presumption would rest with the employer. If, on the other hand, the workman had not been engaged in one of the bracketed processes, he would have to prove that the disease was due to the nature of his employment.

It is not easy to explain in a few lines what was meant by the words "arising out of and in the course of the employment." The spurious simplicity of this phrase is utterly misleading ${ }^{68}$ and only a detailed discussion of the many relevant decisions could do fully justice to it. "Arising in the course of the employment" does not just mean arising during working hours. A worker turning up at his place of employment some time before the hour when he was due to start, say because of transport difficulties, would have been held to have been in the course of his employment as soon as he reached his place of employment. The place of employment was not necessarily the actual factory building or other place where the workman was employed. As soon as the workman reached some place where he had to be or which he had to pass because of the calls of his employment, he was "in the course of his employment." This would apply, for instance, to a private road leading to his employer's premises or even to some means of transport, provided either that he was under a contractual duty to use this means of transport or that by reason of geographical or physical necessity he was bound to use transport provided by his employer. ${ }^{69}$ Where the employment was intermittent (e.g., in the case of railway servants) the workman was still in the course of his employment if he used premises, such as a hostel, made available by his employer, provided that he was compelled to do so. Briefly, then, a man was "in the course of his employment," if he was doing something at the time of the accident which it was his duty under his contract of service to do.

In order that an accident should be held to have arisen "out of the employment,"

${ }^{\circ 0}$ E.g., a wool-sorter contracting anthrax when a germ present in the wool settled in his eye (Brintons Ltd. v. Turvey, [1905] A. C. 230); a seaman infected by paratyphoid fever through eating contaminated food provided on his ship (MoCafferty v. MacAndrews \& Co,, Ltd., [1930] A. C. 599).

or Medical practitioners (now called "appointed factory doctors") appointed by the Chief Inspector of Factories for duties mainly in connection with the administration of the Factories Acts (see \$r26 of the Factories Act, 1937, and $\$ 7$ of the Factories Act, 1948).

os "The subsection wears a specious air of plain speaking." Dods, A Chapter of Accidents: An Essay on the History of Disease in Workmen's Compensation, 39 L. Q. REv. 60, 62 (I923).

${ }^{60}$ St. Helen's Colliery Co., Ltd. v. Hewitson, [r924] A. C. 59. 
the workman had to show that it had been the result of some act or omission on his part, authorized, expressly or impliedly, by his employer. ${ }^{70}$ In other words, an accident "arises out of the employment" if it is based on some risk necessarily incidental to the workman's employment. ${ }^{71}$ If the workman engaged in some activity which was not authorized by his employer, or if he acted in breach of existing work regulations, he was not entitled to claim compensation. The Act contained one important exception to this principle and allowed compensation where the accident had resulted in death or serious and permanent disablement. In such a case even a workman who had been guilty of serious and willful misconduct, or his dependents, could claim.

The persons entitled to compensation were the injured workman himself and, where the injury had resulted in death, his dependents. To be a dependent, a person had to be a member of the deceased's family who had been wholly or partly financially dependent on him. Dependency was always a question of fact, the arbitrator examining whether the deceased had contributed out of his earnings an amount, the loss of which would materially affect the standard of living of the recipient. Other factors were also taken into account, such as any counter-benefits received by the deceased (e.g., his board and lodging).

Turning now to the scale of compensation payments, we must note at once that prior to $1940^{72}$ no account was taken of the family obligations of workmen. The standard rate of compensation in case of total incapacity was $5^{\circ}$ per cent of the average pre-accident earnings with a maximum of 30s. a week. Where the average weekly earnings of the workman were less than 50s., the compensation payments were based on a complicated formula providing for compensation of between 50 and 75 per cent of the wages. Compensation for partial disablement was a weekly sum representing the same proportion of the difference between pre- and post-accident earnings as the weekly payment for total disablement would have borne to pre-accident earnings. ${ }^{73}$ No payment was made for the first three days of disablement, unless the disablement lasted for more than four weeks.

Compensation was payable only where the workman had become incapable of work, partially or totally. The effect of the injury must have been to make the worker's labor unsalable on the market, or salable only at a lower wage than that which he would otherwise have been entitled to expect. Where the workman appeared to be capable of some little work, but this work was not of a type for which there existed a ready market, he was treated as an "odd lot" on the labor market

${ }^{70}$ Wilxis, op. cit. supra note 63 , at $45 \mathrm{ff}$.

71 "The fact that the risk may be common to all mankind does not disentitle a workman to compensation if in the particular case it arises out of the employment." Per Lord Marmoor in Thom v. Sinclair, [rgr7] A. C. 127,145 .

${ }_{72}$ During the war compensation rates were increased and supplements for dependents introduced.

${ }^{73}$ E.g., a worker earned before the accident 605 . a week. Had he been totally disabled he would have been entitled to the maximum compensation of 30s. a week. He was, howcver, able to find work at 40 s. a week. The difference between pre- and post-accident carnings was 20s. and he would have received by way of compensation $\frac{30}{60} \times 20 s$. = Ios. a week. 
and qualified for compensation for total disablement. If the injured worker was unable to find work for reasons other than the result of his injury, e.g., the general economic position of the country, he would not have been entitled to claim compensation.

Instead of receiving weekly compensation payments, the workman could agree to settle his claim against his employer by taking a lump sum in full settlement. Such agreements, in order to be legally valid, had to be registered in the local County Court and the Registrar could refuse registration if he felt that the agreement was unduly prejudicial to the workman's interests. After having paid weekly compensation for six months, the employer had a right, on application to the County Court, to redeem future payments by offering a lump sum settlement amounting to 75 per cent of the capital sum needed to buy a Post Office annuity equal to the weekly compensation payments. A weekly compensation payment received by a workman could be varied at any time on his application or that of his employer, provided circumstances had changed. ${ }^{74}$ Where the workman's post-accident earnings were equal to or higher than his pre-accident earnings, he could get a declaration of liability which would entitle him to have compensation assessed in the future if his earnings should decline because of the after-effects of the injury.

Compensation for a fatal accident took the form of a lump sum payment. Where there were no children ${ }^{75}$ among the dependents, the compensation for total dependency was the equivalent of three years' earnings with a minimum of $f_{2} 200$ and a maximum of $£ 300$ ( $£ 300$ and $£ 400$ after r943). Compensation for partial dependency was such proportion of the above as, in the absence of agreement, was fixed by arbitration. The allowance for child dependents was 55 per cent of the product of the average wage received by the worker (within the limits of $£ \mathrm{I}$ and f2) multiplied by the number of weeks which, at the time of the worker's death, each child had still to go to his fifteenth birthday. The total compensation, including the children's allowance, could not exceed $\oint_{600}$ ( $\$ 700$ after r943) but if some scaling down was necessary, the children's allowance had to be scaled down last.

The settlement of questions as to liability to pay compensation or as to its amount was either by agreement or by arbitration. An agreement, if recorded in the County Court, was enforceable as a judgment. Arbitration was usually before a County Court Judge acting as arbitrator, though the Act envisaged also other forms of arbitration. Appeals from the arbitrator's award were possible to the Court of Appeal and, with the permission of that Court, a further and final appeal could bring the question before the House of Lords.

Most employers took out insurance policies against their liability to pay workmen's compensation. Insurance was, however, compulsory in the coal mining industry only. ${ }^{76}$ Many small employers in other industries failed to obtain insurance

\footnotetext{
${ }^{74}$ E.g.. if the workman's earnings had increased or fallen, or even if the general rate of wages for the occupation which he had followed before his accident had increased.

75 "Children" were all dependents under the age of 15 .

70 Workmen's Compensation (Coal Mines) Act, 1934, 24 \& 25 Geo. 5, c. 23.
} 
coverage with the result that a compensation claim brought them into serious financial difficulties. Where the employer was insured, his rights against the insurers were, in the event of his bankruptcy or liquidation (of a company), transferred to the workmen concerned, so as to allow the latter to claim directly from the insurers up to the limit of the employer's contractual coverage. Where the employer was not insured, the workmen's claims for compensation were treated as preferential debts in the employer's bankruptcy or liquidation.

\section{B. Workmen's Compensation and the Common Law}

After the passing of the first Workmen's Compensation Act in 1897 , claims at common law and under the Employers' Liability Act, x880, declined at first. The I897 Act had not ruled out these alternative remedies, ${ }^{77}$ but where the workman's injury had been caused by the personal negligence of the employer or of a person for whom the employer was vicariously liable, the workman could, at his discretion, proceed against the employer either at common law or under the Employers' Liability Act instead of claiming compensation under the Workmen's Compensation Act. The employer was, however, not liable to pay both common law damages and compensation. Where the workman had elected to take proceedings independently of the Workmen's Compensation Act and his action had failed, the Court, on dismissing his action, could, at his request, immediately assess compensation. The workman would in that event have to pay the costs of his unsuccessful common law action and this liability often nullified any benefit that he might derive from the award of compensation. The workman's legal advisers were thus in a quandary. If they advised their client to proceed at common law he could, if successful, recover substantially more by way of damages than he would have received as compensation. On the other hand, should his action fail, the costs might well swallow up all the compensation awarded to him under the compensation scheme. Unless, therefore, the case appeared to be a clear-cut affair, most legal advisers were inclined to recommend that their clients accept compensation, except where the workman was able to rely on the financial support of his trade union and the union wished to have some legal point finally settled and were prepared to foot the bill.

Since compensation under the Workmen's Compensation Act and common law damages were alternative remedies, the acceptance of one would rule out the subsequent possibility of claiming the other. This led in practice to certain undesirable results. Insurance companies, acting on behalf of employers, often approached a workman, shortly after he had suffered an accident, with an offer of immediate financial assistance. The worker, who perhaps was in financial straits, would accept the money and sign a document that he had agreed to take compensation, thus disabling himself from proceeding subsequently against his employers at common law. A series of House of Lords decisions, culminating in the case of Young v. Bristol Aeroplane Co. $\mathrm{Ltd}_{9}^{78}$ improved the workman's position in this respect. The work-

${ }^{73}$ Cf. $\$ 29$ ( $\mathrm{r}$ ) of the $x 925$ Act.

${ }^{78}$ [1946] I All E. R. 98 . Some doubts have been expressed as to the nature of the principle laid down in this case. Cf. the note on the case by D. W. Hawkins in $62 \mathrm{~L}$. Q. Rev. 119 (1946). 
man's election to accept workmen's compensation was not held binding on him unless he had realized not only that it was compensation under the Act that he was receiving, but also that by receiving it he was precluded from proceeding at common law. It might be noted here that while the workman's rights at common law were of course subject to the usual limitation periods, compensation under the Workmen's Compensation Act could be obtained only if a "claim" for it had been made to the employers ${ }^{79}$ within six months from the date of the accident, or date of death in the event of a fatal accident.

Where the workman's injury had been caused by the negligent act of a third party, the workman could either claim compensation from his employer or damages from the third party. He could not obtain both damages and compensation. If he chose to claim compensation from his employer, the employer was subrogated to the workman's rights against the third party and could claim an indemnity from that party.

\section{Objections to the Workmen's Compensation Scheme}

In the course of the fifty years of operation of the scheme many objections to it were propounded and many attacks directed against it. As witness to that we have a large number of reports of Royal Commissions, ${ }^{80}$ departmental committees, ${ }^{81}$ and private inquiries. ${ }^{82}$ Space does not permit a discussion of these reports in detail, but the following criticisms have been made over and over again.

I. The Complexity of the Set-up. Writing only nine months after the 1897 Act had come into operation, Mr. A. T. Glegg ${ }^{83}$ commented on the plethora of books, articles, critical reviews, etc., that it had engendered. This crop of literature was harvested by those to whom it fell to administer the Act. ${ }^{84}$ Once precedents had been let loose on this branch of law, confusion became even greater. The reader of the standard textbook on the $\mathrm{Act}^{85}$ who had to wade through its 1200 pages, had to be forgiven a smile when noting the pronouncement of an earlier judge who said:86 "It ought to be remembered that the Workmen's Compensation Acts are expressed not in technical but in popular language and ought to be construed not

70 The "claim for compensation" could be a mere notification of intention to proceed under the Act.

${ }^{80}$ Royal Commission of Workmen's Compensatton (Hetherington Commisston) Report, CmD. No. 6588 (1945). The Commission had suspended their work in 1940 and in view of the appointment of the Beveridge Committee they did not continue their investigations afterwards. Some most valuable memoranda of evidence had been published, however, prior to that decision.

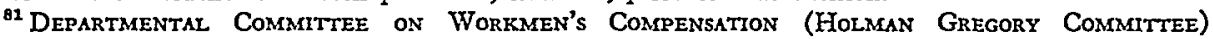
Final Report, Cud. No. 816 (I922). Commitree on Compulsory Insurance (Cassel Commtiee) Final Report, Cmo. No. 5528 (1937). Departmental Commitie on Certain Questions Arising under the Workmen's Compensation Acts (Stewart Committee) Final Report, Cmd. No. 5657 (1938). Interdepartamental Comimittee on Social Insurance and Allied Services (Beveridge CoMmittee) Report by Sir William Beveridge, CMm. No. 6404 (1942).

${ }^{82}$ ARnold Wilson and Herarann LeVY, Workmen's Compensation, Vol. I (1939); Vol. II (I94I).

${ }^{83}$ The Workmen's Compensation Act, II JuRID. Rev. I37 (1899).

se "Some showed a tendency to be smart at the expense of legislators, while others found dificulties where none existed, but for the most part the decisions showed that the bone thrown to them was not one of scrious contention." Glegg, supra, at I37.

${ }^{80}$ See note 63 , stipra.

${ }^{80}$ Romer, L. J., in Smith v. Coles, [1905] 2 K. B. $827,830-83$ r. 
in a technical but in a popular sense." A. H. Ruegg, K. C., a County Court Judge with considerable experience in the administration of the scheme, was more candid about the real position. Writing in the same year, he said:87 "Before the Workmen's Compensation Act was passed, I was under the impression that I knew what "personal injury by accident' meant. Now, I am far from sure that I do." Giving evidence before the Holman Gregory Committee, ${ }^{88}$ Judge Ruegg again emphasized that the Act was "very technical" and that it was difficult to succeed under it. No wonder then that the ordinary workman failed to have any confidence in an Act which he simply could not understand.

2. Litigation. When the 1897 Act was passed, it was hoped that the new scheme would reduce the amount of litigation. ${ }^{80}$ The only sense in which events justified this hope was in the eclipse of actions under the Employers' Liability Act. While there were still $5^{8} 3$ cases under this Act in 1907 , the extension of the workmen's compensation scheme in that year led to a rapid decline so that by 1938 (the last year for which complete statistics are available) the number had fallen to $42 .{ }^{90}$ At first, the new workmen's compensation legislation led also to a fall in common law actions, but with the gradual erosion of the defence of common employment and the extension of statutory liabilities of employers, the number of common law cases increased again. The total number of workmen's compensation cases taken to court in 1938 was $5,4 \mathrm{rg}$, of which, however, only $\mathrm{r}, 845$ were original claims for compensation. $^{91}$ It is impossible to say how many claims were settled out of court, but it has been suggested ${ }^{92}$ that the claims submitted to litigation were no more than 2 per cent of the total of claims. We may fairly surmise that in many of the cases settled out of court, the claimant was persuaded to accept a smaller compensation than he would have been awarded by an arbitrator. The cost of legal proceedings, the uncertainty of outcome, fear of loss of employment, ${ }^{93}$ and general shortage of money must have induced many workmen to settle their claims privately.

A large proportion of the litigation referred to was probably unnecesary and has been ascribed to the activities of insurance companies. ${ }^{94}$ They were accused of entering wantonly into long drawn-out litigation in order to compel the workman to agree to some unfavorable settlement. Their touts were alleged to pursue injured workmen in hospitals or their families at home, preying upon their fear and ignorance so as to be able to settle their claims as cheaply as possible. Much

s7 The Laws Regulating the Relation of Employers and Workmen in England 153 (I905).

${ }^{38}$ Holman Gregory Committee, Minutes of Evidence. A. 10263.

${ }^{89}$ BeVeridge Report; CMD. No. 6404 at 36, par. 79( $(\mathrm{r})$.

${ }^{\circ 0}$ Workmen's Compensation Statistics for i938. CMD. No. 6203.

${ }^{21}$ In 1,405 cases, i.e., 76.2 per cent of the total, the applicant was successful.

${ }^{92}$ CMD. No. 6203, at $\mathrm{r}_{4}$.

93 "Experience. . . showed that whether the injured workman recovered damages or not, he lost his employment if and when he pressed his suit, even if his disability was but temporary." I WILsoN AND LEVY, op. cit. supra note 82 , at $5 \mathrm{I}$.

94 "My conchusion . . . is that the system of insuring against employers' liability has promoted a quite unnecessarily large amount of litigation in the sphere of workmen's compensation. . . ." Robson, Industrial Law, 51 L. Q. Rev. 195, r99 (1935). 
evidence of this type was submitted to the Holman Gregory Committee and the Hetherington Commission ${ }^{96}$ and although the insurance companies denied the allegations made against them, there can be little doubt that many malpractices occurred.

3. Safety. It has been one of the main defects of the workmen's compensation scheme that it disregarded the question of industrial safety. ${ }^{96}$ Compensation can merely alleviate the financial effects of an injury, it cannot restore the injured worker to health. The authors of the legislation had assumed that the liability of paying compensation to injured workmen would induce employers to take greater care for their safety. ${ }^{97}$ Experience showed that this belief had been misplaced. Two of H.M. Inspectors of Factories, Commander Smith, R.N., ${ }^{\mathbf{9 8}}$ and Mr. Gerald Bellhouse, ${ }^{99}$ stated that employers were less interested in safety since they had insured against employers' liability. Employers who had insured against this liability had no real incentive to increase safety in their factories. Premium rates depended on the industry group of the employer on the basis of a schedule issued by the Accident Offices Association; no distinction was made between careful and careless employers. "Special rates" were granted to employers in whose factories over a period of two or three years accident risk had been shown to be low, but fewness of accidents does not as such prove that safety arrangements are adequate. ${ }^{100}$ The standards of safety were probably highest in the larger companies carrying their own insurance risk. ${ }^{101}$

The workmen's compensation scheme embodied no arrangements for the medical treatment of injured workers. Doubtless, most workmen were contributors to the compulsory national health insurance scheme, but some 900,000 persons covered by the Workmen's Compensation Acts were not subject to compulsory health insurance. ${ }^{102}$ The health insurance scheme in those days provided for a minimum of benefits only, the range of the benefits depending on the approved society to which the contributor belonged. Few insured persons were entitled to facilities to help them with their convalescence.

4. The amount and the assessment of compensation. Adequacy of compensation was never a guiding principle of the workmen's compensation scheme. From its very start it was assumed that the injured workman should himself bear a proportion of the loss. ${ }^{103}$ Before 940 the most that an injured workman could obtain by way of compensation was 3 os. a week. B. S. Rowntree, who has made a number of

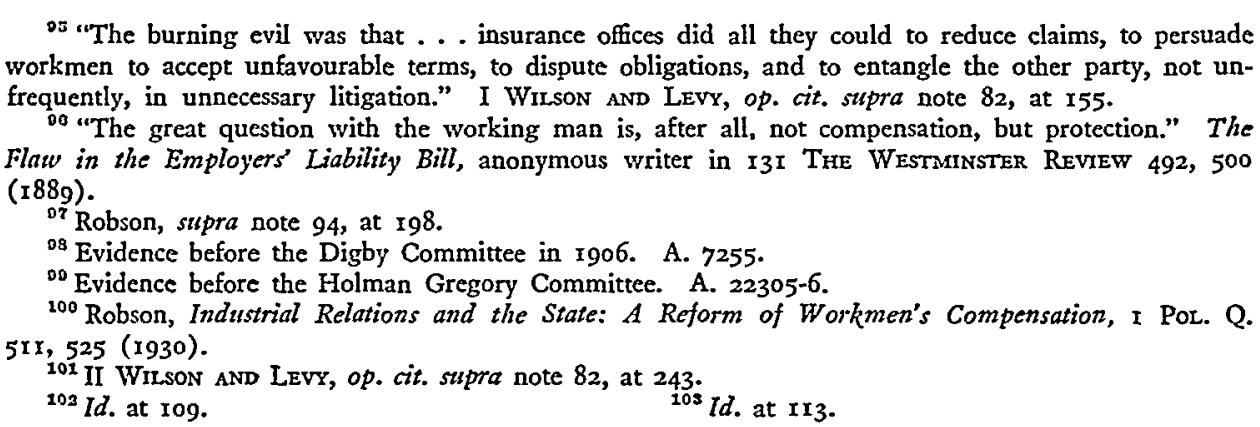


studies of the workers' standard of living, estimated that on the basis of 1936 prices, a married urban worker with three children would require $53 \mathrm{~s}$. a week to maintain mere physical efficiency ${ }^{104}$ Thus, while the rate of compensation could conceivably suffice for the needs of a single worker, or for a married worker whose family was self-supporting, it was undeniably inadequate for a married man with a dependent family. Insufficiency of food and financial worries often tended to retard the recovery of the injured man.

The method of assessment, based on the difference between pre- and post- accident earnings, was also open to attack. The wages earned immediately prior to the accident were often a poor guide to the worker's then earning capacity. Equally, the hypothetical amount which the worker was supposed to be capable of earning after the accident often bore little relation to the real position. Many a workman was found capable of "light work" irrespective of whether such "light" work was available at all, or for the worker in particular. It is not surprising that patients were said to be afraid of improving because they could then be classed as able to do light work. ${ }^{105}$ Much depended, of course, on the medical assessment and it was regrettable that this should have led to the creation of a class of professional medical witnesses regularly appearing for insurance companies. ${ }^{106}$

Lump sum settlements were strenously opposed by trade unions. ${ }^{107}$ They were objected to because they tended to unsettle the recipient by giving him what may have appeared to be a substantial sum of money. This capital sum was often improvidently invested or used up for daily expenditure, ${ }^{108}$ leaving the workman then dependent on the poor law. Many workmen resisted the offer of a lump sum settlement until the accumulation of debts forced them to give way.

The absence of any compulsion on employers to take out insurance coverage against their legal liabilities ${ }^{109}$ meant that many servants of smaller employers, such as craftsmen, were unable to recover anything from their employers. Compulsory insurance was often demanded but the government refused to consider it. It was said that a varying premium rate would be administratively difficult and that a flat premium rate would be unfair and would remove from the employer the incentive to reduce risks. ${ }^{110}$ In any case, with private insurance as expensive as will be pres-

${ }^{204}$ B. S. Rowntree, The Human Needs of Labour (1937).

${ }^{106}$ Dame Agnes Hunt, Final Report of the (Delevigne) Committee on the Rehabilithtion op Persons INJUREd IN ACcidents 54 (1939).

${ }^{100} \mathrm{II}$ WILSON AND LEVX, op. cit. supra note 82 , at $\times 85$.

107 "All lump sum settlements are speculations in connection with the Compcnsation Act." S. Chorlton, General Secretary of the National Union of Railwaymen giving evidence before the Holman Gregory Committee. A. $27 \times 2$.

108 "Lump sum settlements dislocate the victim's social habits and mental outlook and those of his family; tempt him into a ruinous entry into business, in which he is not qualified to succecd; engender resentment inimical to the preservation of social solidarity and induce victims to prolong their incapacity by an allurement not shared by weekly allowances paid under the Act." 8 Charity Organisation Quartercy ro5 (July, I934).

${ }^{109}$ Such compulsion existed, of course, in the coal-mining industry.

${ }^{110} \mathrm{Cf}$. the speech by Neville Chamberlain in the House of Commons, May 18, x925. 184 H. C. DEB. 75-76 (5th. ser. 1925). 
ently shown, the idea of compelling employers to insure was not politically practicable. ${ }^{111}$

5. The coverage of the scheme. The workmen's compensation scheme never covered all employed persons. It did not apply to non-manual workers earning more than $£ 350$ p.a. ( $£ 420$ as from I942). Available statistics do not clearly indicate how many persons were in fact under the scheme, but the drawing of the line at the above figure was hardly justifiable since few people with incomes just above the dividing line were able to make independent provision for the event of their being injured at work.

6. The cost of the scheme. The strongest criticism of the workmen's compensation scheme was that, in relation to the benefits which it offered to workmen, it was much too expensive. Most employers had some form of insurance coverage either with commercial insurance companies ${ }^{112}$ working for profit or through some mutual insurance association. The Beveridge Report contains the following revealing figures ${ }^{113}$ of the distribution of premium income. The figures represent the average of the years 1938 and 1939 .

It is evident that for every $f_{0}$ roo received by way of premium, the commercial

\begin{tabular}{|c|c|c|c|c|c|c|c|c|c|c|c|}
\hline \multirow{2}{*}{$\begin{array}{l}\text { Premiums } \\
\quad f 000\end{array}$} & & \multicolumn{2}{|c|}{$\begin{array}{l}\text { Commis- } \\
\text { sion }\end{array}$} & \multicolumn{2}{|c|}{$\begin{array}{l}\text { Manage- } \\
\text { ment } \\
\text { Expenses }\end{array}$} & \multicolumn{2}{|c|}{$\begin{array}{c}\text { Legal \& } \\
\text { Medical } \\
\text { Expenses }\end{array}$} & \multicolumn{2}{|c|}{ Profit } & \multicolumn{2}{|c|}{$\begin{array}{c}\text { Total } \\
\text { Cost of } \\
\text { Adminis- } \\
\text { tration }\end{array}$} \\
\hline & & $f^{\prime} 0$ & $\%$ & $f^{\prime} 0$ & of & $f^{\prime} 000$ & $\sigma$ & $f^{\prime} 0$ & of & $f^{\prime} \cap 00$ & $\%$ \\
\hline $\begin{array}{l}\text { Accident Offices } \\
\text { Association....... }\end{array}$ & 4,600 & 399 & 8.7 & $|1,235|$ & 26.8 & 214 & 4.7 & 290 & 6.3 & $\mid 2,138$ & 46.5 \\
\hline $\begin{array}{l}\text { Mutual Insurance } \\
\text { Companies Associations.... }\end{array}$ & 7,182 & 316 & 4.2 & 824 & 11.5 & 385 & 5.4 & 25 & .4 & || $1,550 \mid$ & 21.6 \\
\hline
\end{tabular}

insurance companies paid out only $£ 53$ ros.od. to workmen and the mutual insurance associations $£ 78$ ss.od. The low return shown by insurance companies was not caused by high profits, but by high maangement expenses. ${ }^{114}$ The following reasons for the high expense ratio have been suggested: ${ }^{115}$

112 "No Government could ask Parliament to compel manufacturers to support a system of profitmaking insurance so wasteful and exorbitant as that which now prevails in this counery." Robson, supra note 100, at 524 .

${ }^{112}$ Most of the large insurance companies were members of the Accident Offices Association.

${ }^{113} \mathrm{CMD}$. No. 6404 at 280 (1942).

12s In 1923 the Accident Offices Association gave an undertaking to the Home Secretary to the effect that the members of the Association wotld from time to time adjust their premium rates on workmen's compensation insurance so as to make the "loss ratio" (i.e., the proportion which the total amount set aside for claims, including reasonable medical and legal expenses, bears to the total of premiums received) not less than 60 per cent for the first three years (r924-1926) and thereafter not less than $621 / 2$ per cent, or such other proportion, not less than 60 per cent, as might be agreed with the Home Secretary. (CMD. No. I8I9 (I925)). See also Robson, Industrial Relations and the State, I Pot. Q. $5 \mathrm{Ir}, 518$ (1930). It should be noted that the Holman Gregory Committee had in I922 recommended a compulsary 70 per cent loss ratio (CMD. No. $8 \times 6$ at 20, par. 22). The Accident Offices Association estimated the average percentage of medical and legal expenses included in the amount set aside for claims as being in the years $x 935$ and $19364 \frac{1}{2}$ per cent of the total of compensation payments.

${ }^{115}$ II WiLson atid LeVY, op. cit. supra note 82 , at 336 . 
a. Duplication of services among competing companies.

b. Overstaffing, particularly among agents (this was also a result of excessive competition).

c. The small volume of business of some of the smaller companies in relation to their fixed overhead expenses.

d. The high cost of litigation.

In view of the variety of insurance bodies in existence, there are no accurate estimates available of the total cost to employers of workmen's compensation and employers' liability at common law. Cmd. No. 6203 (note 90, supra) estimated the cost at just under $f_{13} 1 / 2$ millions for 1938 . A later White Paper, introducing the government's proposal for a scheme of social insurance, ${ }^{116}$ estimated the pre-war cost at $£$ Io millions together with some $£ 3$ millions in administrative expense to employers. ${ }^{117}$

\section{III}

\section{The Natronal Insurance (Industrial Injuries) Act, 1946}

\section{A. The provisions of the Act}

The National Insurance (Industrial Injuries) Act, $1946^{118}$ did not introduce such revolutionary changes in this branch of our law as is often assumed. Its main innovations are in the field of administration rather than in questions concerned with entitlement to benefit. The intellectual father of the new set-up is Lord Beveridge, who, as Sir William, in his famous Report on Social Insurance and Allied Services, submitted to the Coalition Government in $1942,{ }^{110}$ outlined the framework of the scheme. Beveridge's proposals were not entirely accepted by the Government. $^{120}$ The Government, for instance, did not agree to his suggestion for an industrial levy on industries treated as particularly dangerous. ${ }^{121}$ It fell to the first post-war Labour Government to introduce the necessary legislation, which, in view of the scheme's Coalition parentage, was passed without much opposition.

In a broad outline of the law such as the present one it is of course impossible to give full details of all aspects of the scheme. Benefit rates have been already increased twice, in $195 \mathrm{I}^{122}$ and $1952,{ }^{123}$ and many administrative changes have been made in the light of experience. Our main aim is to show where and how the new scheme differs from its predecessor. Points of purely administrative interest will be disregarded.

${ }^{110}$ CMD. 655I (x944).

117 The total paid out by business enterprises in 1938 on account of wages and salaries has been estimated at $£ 2475$ millions so that the cost of compensation cannot have come to more than .6 of one per cent of the total labor bill. Of course, not all persons in receipt of wages or salaries were covered by the workmen's compensation scheme. (White PAPER on NATional Income and Expenditure of the UNITED KINGDOM, I938-I946, CMD. No. 7099 at ro, table 7 (1947)).

${ }^{128} 9$ \& ro GEO. 6, c. 62 . The Act will be referred to herein as the Industrial Injurics Act.

119 CMD. No. 6404. ${ }_{120} \mathrm{CMD}$. No. $655 \mathrm{r}$.

122 Beveridge Report, CMD. No. 6404 at 138 , par. 360 .

122 National Insurance Act, 195I, I4 \& 15 GEo. 6. c. 43.

${ }^{193}$ Family Allowances and National Insurance Act, 1952. 15 \& 16 GEo. 6, \& I Eurz. 2, c. 29. 
The scheme is administered by the Ministry of National Insurance which, as from April I, I945, has taken over all the functions of the Ministry of Labour and National Service in connection with the previous unemployment insurance scheme and which also prepared the ground for the commencement of the industrial injuries scheme as from July 5 , r948. The industrial injuries scheme forms a part, though financially a separate one, of the general national insurance scheme provided under the National Insurance Act, I946. ${ }^{124}$ All persons working under a contract of service (as distinct from a contract for services) are treated as being in "insurable employment."125 The weekly contribution ${ }^{120}$ payable by the insured person is deducted from his wages or salary and a single stamp is attached by the employer to the insured person's insurance card, covering the employer's and the insured's contributions both under the industrial injuries and under the national insurance schemes. ${ }^{12 t}$

Benefit under the scheme is payable "for personal injury caused on or after the appointed day ${ }^{128}$ by accident arising out of and in the course of the employment." It will be seen that these words reproduce the phrasing of section $I(I)$ of the Workmen's Compensation Act, I925, and, with certain exceptions to be mentioned later, they have also been interpreted in the same way. "Personal injury" which under the workmen's compensation scheme meant "injury leading to incapacity to work," includes now also disfigurement even though the insured person's capacity to work has not been impaired. The Act also provides that an accident "arising in the course of the insured person's employment" shall be deemed in the absence of evidence to the contrary to have arisen "out of the employment." The burden of proof regarding the causation of an accident does not rest then with the claimant for benefit. This is of particular importance where the insured person was killed at work in circumstances where the cause of his death is not clear.

The Industrial Injuries Act has also changed the rules applicable to injuries sustained on the way to or from work. Under the earlier legislation a workman was able to claim compensation only if at the time of his accident he was doing some-

1249 \& 10 Geo. 6 , c. 67 .

${ }^{125}$ All persons in such employment are insured, irrespective of the nature of the employment or of their income.

Certain employments are excepted from insurance. They include:

(a) Prescribed (i.e., by regulations) employment under a public or local authority constituted in Great Britain;

(b) Employment as a member of the crew of a foreign ship or aircraft;

(c) employment of a casual nature which is not undertaken for the purposes of the employer's trade or business; and

(d) employment in a private dwelling house by a close relative.

${ }^{120}$ At present the contribution rates are $4 \mathrm{~d}$. for men over 18 and $3 \mathrm{~d}$. for women over 18 with smaller amounts for those under this age. The employer pays $5 \mathrm{~d}$. for a male employee and $3 \mathrm{~d}$. for a female employec. The Exchequer also makes a contribution to the Industrial Injuries Fund.

${ }^{127}$ In passing it may be noted that there are persons liable to insurance under the industrial injuries scheme who are excepted from the payment of contributions under the general scheme, e.g., persons over retirement age who are continuing to work, and married women in employment who have elected not to pay contributions. On the other hand, self-employed and non-employed persons contribute under the general scheme but not under the industrial injuries scheme.

${ }^{128}$ I.e., July 5 , 1948 . 
thing, such as traveling on a particular vehicle, which he was contractually bound to do in relation to his employer. Now, an accident is deemed to have arisen out of and in the course of the employment if it has happened while the insured person was traveling on a vehicle to or from his place of employment and the vehicle was operated by or on behalf of his employer even though the insured person was not compelled to use it.

The position regarding industrial diseases is roughly the same as under the Workmen's Compensation Acts. A disease may be a personal injury by accident where it has instantaneously affected the workman. Benefit is, however, also granted where the disease is a prescribed one and the insured person has been employed in one of the named occupations.

Benefits under the scheme may be divided into three classes. Injury Benefit (at present 55 s,od. a week) is payable while the insured person is incapacitated from work, with a maximum of six months. ${ }^{129}$ At the end of the six month period, or earlier if the insured person's incapacity terminates before then, he has to undergo a medical examination to determine the "degree of loss of mental or physical faculty." ${ }^{\text {"130 }}$ On the basis of this assessment by a medical board the amount of disablement benefit payable to the insured person will be fixed. In order to qualify for this benefit, the loss of faculty either must be likely to be permanent (e.g., the loss of a finger or eye) or must be substantial. ${ }^{131}$ The degree of loss is measured on a percentage basis, regulations ${ }^{132}$ having laid down percentage equivalents for the most common injuries.

Disablement benefit may take the shape of either a disablement gratuity (where the loss of faculty is under 20 per cent) or of a disablement pension (where it is over 20 per cent). No benefit is payable for loss of faculty assessed at less than $x$ per cent. The disablement gratuity is a lump sum payment of $\oint_{6} 85$ for loss of faculty of 20 per cent with correspondingly smaller amounts for lesser disablement. The pension is payable at a weekly rate of 55 s.od. for yoo per cent loss of faculty, ${ }^{133}$ with correspondingly lower rates for loss of faculty of less than roo per cent. ${ }^{134}$ In addition to the standard rate certain supplements may become payable. Where the beneficiary is incapable of work $\mathrm{k}^{135}$ he may qualify for an unemployability supplement of $32 \mathrm{~s} .6 \mathrm{~d}$. a week. Where he is in need of constant attendance he may get an allowance of between 25s.od. and 5os.od. a week. As loss of faculty is assessed on the basis of the effect of the injury on a normal human being, no account is taken of the occupation of the claimant and of any special hardship which he might suffer in consequence of the injury. In order to provide for such cases and to compensate a

\footnotetext{
${ }^{120} \mathrm{Men}$ and women receive the same rates of benefit. A married man is entitled to a supplement for his wife of $215.6 \mathrm{~d}$. a week (provided that the wife does not carn more than $40 \mathrm{~s}$. on her own account) and to a supplement of zos.6d. per child. The family allowance of $8 \mathrm{~s}$. for the second and further children is, however, included in the child allowances.

${ }^{130}$ Loss of physical of mental faculty means some impairment of the power to enjoy a normal life. ${ }^{131}$ A substantial disablement is one assessed at more than 20 per cent.

${ }^{182}$ The National Insurance (Industrial Injuries) (Benefit) Regulations, 1948. S. I. 1948, No. 1372.

${ }^{133}$ E.g., loss of both hands, complete deatiness, loss of sight.

${ }^{134}$ E.g., 27s.6d. for 50 per cent loss of faculty.

${ }^{135} \mathrm{~A}$ person is incapable of work if he is unlikely to earn more than $£ 52$ in a year.
} 
claimant for not being able to follow his particular pre-accident occupation with consequent financial loss to him, the insured person may qualify for a special hardship supplement of up to 20s. a week. ${ }^{136}$ Allowances for wife and children are also payable at the same rates as for injury benefit, but only to claimants who are either in receipt of an unemployability supplement or are undergoing approved hospital treatment. $^{137}$

The third type of benefit available under the scheme is death benefit, payable where the insured person met with a fatal accident. The persons entitled to claim this benefit are the widow or widower (where he was dependent on his wife for his maintenance), the children, and, where dependency can be proved, parents and certain other relations. The Industrial Injuries Act has done away with the much criticized practice of making lump-sum payments. ${ }^{138}$ Widows are entitled to a widow's pension of $42 \mathrm{~s} .6 \mathrm{~d}$. for the first thirteen weeks of widowhood. After that period, the widow may qualify for a penion of either $375.0 d .^{139}$ or of 20 s.od. Both pensions are payable for life or until remarriage. In the latter event the widow will receive a gratuity equal to one year's pension.

Claims for benefit are submitted in the first place at a local office of the Ministry of National Insurance. There are no "contribution conditions" so that benefit may be claimed even after a single day of insurable employment. If benefit is refused or some supplement asked for is disallowed, the insured person may appeal to a local appeal tribunal. The members of these tribunals are chosen by the Minister. ${ }^{\mathbf{1 4 0}}$ From the tribunal it is possible to make a final appeal to the Industrial Injuries Commissioner, ${ }^{141}$ subject to the consent of either the chairman of the tribunal or of the Commissioner himself. The decisions of the Commissioner are final and not subject to revision by the courts. The most important decisions are published by H. M. Stationery Office, giving rise thus to a kind of insurance case law. ${ }^{\mathbf{1 4 2}}$ Certain questions (called "special questions") ${ }^{143}$ must be submitted by the local insurance office to the Minister for decision. The Minister's decision in these cases, which deal with issues fundamental for the scheme, is subject to an appeal to a Judge of the High Court. The insurance officer is bound by the assessment of a person's loss

${ }^{138}$ The total of pension plus supplement may not exceed in this case 55 s. a week.

${ }^{137}$ In order to encourage injured workers to regain health, they will receive disablement benefit at the maximum rate while undergoing approved hospital treatment, notwithstanding the fact that their "loss of faculty" is less than roo per cent.

${ }^{138}$ Lump sum gratuities are still payable to parents and other relations provided they were not mainly dependent on the deceased for their support (in which case they would receive a pension) and as has been shown already disablement gratuities also take the form of lump sum payments.

${ }^{130}$ The higher rate is payable where the widow

(a) has one or more children under 16 , or

(b) is permanently incapable of self-support, or

(c) is, or reaches, the age of 50 .

${ }^{140}$ One person each is taken from panels representing employers and insured persons respectively. The chairman is selected independently by the Minister.

141 The Commissioner is appointed directly by the Crown and not by the Minister. The present holder of the office is a County Court Judge.

${ }^{149}$ A discussion of these decisions has recently appeared in book form. H. KEAST, CASE LAw of National, Insurance and Industrial Injuries (1952).

${ }^{143}$ These questions deal with such matters as to whether a person is in an insurable employment, who is the employer of an insured person, etc. 
of faculty made by the medical board, but both the Minister and the claimant for benefit may appeal from the board's decision to a medical appeal tribunal.

It has been already stated that the industrial injuries scheme replaced the workmen's compensation scheme as from July 5, x948. The change-over did not affect existing compensation awards which remained as hitherto the responsibility of the employer against whom they had been given. A person in receipt of workmen's compensation may, however, qualify for unemployability supplement and also for an allowance for constant attendance which will be paid out of the Industrial Injuries Fund. ${ }^{144}$ In order to qualify for insurance benefits a person must have been employed after July 5, I948 in an insurable employment. There are special provisions to deal with industrial diseases contracted before that day which have led to incapacity to work after it. ${ }^{145}$

\section{B. National Insurance and the Common Law}

Where a person suffers an injury in circumstances entitling him both to common law remedies against some other party and also to benefits under the national insurance scheme, there exists now no longer any need to elect which remedy to apply for. The unsatisfactory nature of the rules relating to "alternative remedies" and the proposed introduction of a national insurance scheme led to the appointment in July I944 of a departmental committee under the chairmanship of Sir Walter T. Monckton, K.C. to consider this and certain allied issues. In their Final Report ${ }^{146}$ the committee referred to the passage in the Beveridge Report ${ }^{147}$ in which Lord (then Sir William) Beveridge had laid down the principle that "an insured person should not have the same need met twice over." This principle underlies the entire national insurance scheme in that an insured person can never claim two benefits for the same contingency. ${ }^{148}$ Applying this principle to the case of alternative remedies, Lord Beveridge had suggested that it could be put into operation either by scaling down the amount of damages at common law or by insisting on a refund to the Industrial Injuries Fund of benefits received already where the recipient had been subsequently awarded common law damages. Since the Beveridge Report did not suggest which of these solutions should be adopted, the matter was referred to the Monckton Committee. The majority of this committee recommended that in assessing common law damages the court should take into account in diminution of the damages any financial benefits received or receivable by the plaintiff under the national insurance schemes. The trade union members ${ }^{\mathbf{1 1 0}}$ of the committee dissented from the majority and recommended that the plaintiff in such cases should be entitled to full damages, while two other members ${ }^{150}$ of the com-

\footnotetext{
244 The National Insurance (Industrial Injuries) (Benefit) Regulations, I948. S. I. 1948 No. 1372, Regs. 32 and 33.

${ }^{145} \mathrm{Sec} .89(\mathrm{r})$ of the Industrial Injuries Act. See also Hales v. Bolton Leathers, Ltd., [195x] 1 T. L. R. 570 .

${ }^{140}$ Final Report of the Departzantal Committee on Alternative Remedies, Cmd. No. 6860 (I946). Two Interim Reports had been published in January 1945 (CMD. No. 6580) and in May I945 (CMD. No. 6642).

${ }^{147}$ CMD. No. 6404 at 260 , par. Ior.

${ }^{148}$ E.g., industrial injury benefit and unemployment or sickness benefit.

${ }^{149}$ Messrs. W. P. Allen and L. Fawcett. $\quad{ }^{150}$ Messrs. J. S. Boyd and G. de G. Warren.
} 
mittee suggested that some ceiling should be placed on the amount of damages awarded at common law against an employer.

The Labour Government adopted a compromise solution to this problem in the Law Reform (Personal Injuries) Act, r948. ${ }^{151}$ The Act provides that in an action for damages for personal injuries the court, in assessing damages, should take into account one half of the financial benefits that have accrued or probably will accrue to the plaintiff in respect of industrial injury benefit, industrial disablement benefit, ${ }^{152}$ or sickness benefit for a period of five years from the time when the cause of action arose. No such deduction applies, however, where the action is brought by the dependents of a deceased person under the Fatal Accidents Acts.

It should be noted that the deduction of benefits applies not only in favor of an employer, who of course has himself made contributions to the Industrial Injuries Fund, but also in favor of any third party who may have been responsible for the plaintiff's injury.

\section{General assessment of the Act}

It is too early yet to present a general assessment of the industrial injuries scheme. The government actuary will have to prepare a report on the financial condition of the Industrial Injuries Fund by I954 and that perhaps will lead to a re-consideration of the principles on which the scheme is based.

If we look at the scheme in the light of the objections raised against its predecessors, it must be admitted that most of the objections have been accounted for. Of course, those who felt that all the "legalistic nonsense" about "accidents arising out of and in the course of the employment" should be dropped, must have been disappointed by the developments. ${ }^{153}$ Hard cases there have been as before, but by and large the administration has been wise and humane.

The benefit rates applicable under the scheme are far more generous than those awarded for similar contingencies under the general national insurance scheme. ${ }^{154}$ There are doubts as to what constitutes today a minimum income necessary to avoid sheer poverty. Messrs. B. S. Rowntree and G. R. Lavers in a survey of social conditions in York ${ }^{165}$ have fixed the poverty line for a family of five at 1950 prices at $f_{5}$ os.2d. Now, in 1950 a Ioo per cent disabled workman with wife and three children under 16 would have received under the industrial injuries scheme (including family allowances) $£ 318 \mathrm{~s} .6 \mathrm{~d}^{156}$ and would thus in the absence of other income be suffering from poverty. Of course, he or his wife could have some earnings of their own $\mathbf{n}^{167}$ and the family would also qualify for national assistance if their

${ }^{261}$ II \& 12 GEo. 6, c. 4x. This was the Act which also abolished the doctrine of common employment.

${ }^{152} \mathrm{An}$ increase in respect of constant attendance will be disregarded.

${ }^{203}$ E.g., Turner-Samuels, Industrial Injuries Acts, 1946-r948, 6 IND. L. REv. 266 (1952).

${ }^{2 t}$ Compare, for instance, injury benefit at $55 \mathrm{~s}$. a week with sickness benefit at $325.6 \mathrm{~d}$. a week. For the reasons for the special treatment of industrial injuries, see the BEvERIDGE REPORT, CMD. No. 6404 at 39 , pars. $8 \mathrm{I}-83$.

${ }_{165}$ Poverty ANd THE Welfare State (195I).

${ }^{150}$ This docs not include an unemployability supplement or allowance for constant attendance to which the insured person may be entitled.

${ }_{157}$ If the husband receives a supplement on her behalf she may not earn more than 405 . a week, otherwise the supplement would cease. 
income was to be found insufficient to meet their needs. Since 1950 benefit rates have gone up but so have prices and the position is unlikely to be much different. Insurance benefits do not meet the full needs of the family man who has become totally incapacitated. They are of help to the partially incapacitated person since the benefit will not be adjusted for any earnings of which he is capable. He has thus an incentive to secure his earliest possible rehabilitation. Similarly, injury benefit is probably sufficient for the temporary need which it is supposed to meet. It is paid promptly ${ }^{158}$ within a matter of a few days after the claim for it has been submitted; there is no need to go to the law or to persuade an unwilling insurance company to pay up.

As far as the rehabilitation of injured workers is concerned, we ought to remember that the national health service scheme has made medical and hospital treatment and the provision of medicines and surgical and other appliances freely available $\mathrm{e}^{150}$ to all members of the community. The Ministry of Labour and National Service has also arranged courses of instruction which will help disabled persons to find a place in industry. ${ }^{100}$ The Disabled Persons (Employment) Act, 1944, imposes on all employers of more than 20 persons an obligation of employing a quota of disabled persons ${ }^{101}$ so that even the partially disabled need no longer fear that they will be unable to secure employment because of their disability.

The employer finds himself probably better off under the present scheme than he did in the past. Comparative figures are not available, but in the first year of the operation of the industrial injuries scheme the total contributions from employers and insured persons amounted to $£ 20,450,000{ }^{102}$ Since employers pay half

${ }^{158}$ No benefit is payable for the first three days of incapacity unless incapacity continues for twelve days. Two or more consecutive days in a week may be added up to reach the required twelve, provided they fall within a period of thirteen consecutive weeks.

${ }_{150}$ Subject, at present, to a small charge of Is. for every prescription. Patients also have to pay for part of the cost of some of the more expensive appliances, e.g., hearing aids. The Industrial Injurics Act provides (\$75) that artificial limbs should be made available and maintained free of charge or at a reduced charge to insured persons who have become incapacitated.

${ }^{160}$ Disabled Persons (Employment) Act, I944, $7 \& 8$ GEo. 6, c. I0, $\$ \$ 3-4$; also Industrial Injurics Act, \$74. A description of the facilities available may be found in M. P. Hall, The Soctal Senvices or Modern England (1952).

161 The quota stands at present at 3 per cent.

102 Report of the Ministry of Nattonal Insurance, 1944-1949, CMD. No. 7955 at 6I (1950). The position of the National Insurance (Industrial Injuries) Fund in the second year of the operation of the scheme was as follows:

\section{RECEIPTS}

Contributions from employers and insured persons

Exchequer contributions Income from investments Other receipts

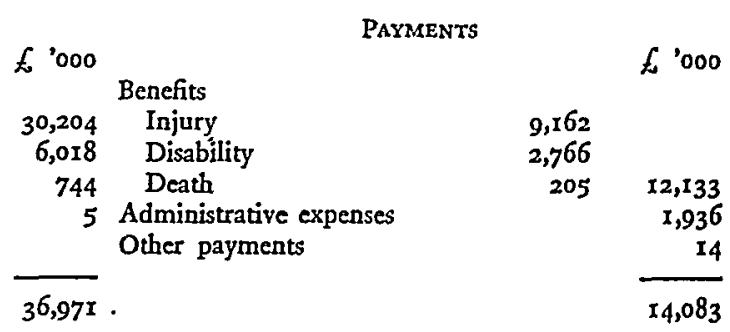

The excess of receipts over payments for the year ended March 30, r950 amounted thus to £22,888,000. (The table is taken from the SECOND Report of THE Ministry of National INsurance For tiID Period July 5, I948-December 3I, I950, CMid. No. $84 \mathrm{I2}$ at 48 (r95I)). The expenses of the Industrial 
the total contributions, the cost of the scheme to them must have been about $\mathrm{Exo}^{1 / 4}$ millions. It has been suggested that the cost of workmen's compensation to employers, excluding administrative costs, amounted during the war to some $f_{\mathrm{I}} \mathrm{I}$ millions and it would have been much higher now. In order to make a fair comparison it would, of course, be necessary to bring into account also the cost of insurance against employers' liability at common law the need for which has not disappeared. ${ }^{1622}$ Perhaps the position might be summed up by saying that employers in safe industries may find themselves now slightly worse off and those in dangerous trades better off since, unlike private insurance, the industrial injuries scheme does not discriminate between different industries.

Although comparisons in this field are difficult, there appears to be no evidence that accidents in industry are now fewer in numbers though there has been a fall in the number of fatal accidents. ${ }^{163}$

This brings us to the last issue-namely, the future of the industrial injuries scheme in a period of inflation. When the scheme was proposed first in the Beveridge Report, the underlying assumption was that prices after the war would tend to settle down. ${ }^{104}$ The benefits suggested were all calculated carefully on the basis of such prices as might be expected at the end of the war. Prices have, however, continued to rise and what might have been just about adequate benefits have become grossly inadequate ones. On two occasions (I95I and 1952) already national insurance benefits had to be reviewed. In each case this meant the passing of an Act and the making of many new orders and regulations. The administrative difficulties must have been enormous: pensions had to be reviewed, pension books amended,

Injuries Fund in this period amounted to a mere 5.4 per cent of its receipts, but then the payments to insured persons took up only 33 per cent, showing thus a profit of 6 t. 6 per cent. This profit went towards building up the Industrial Injuries Fund which, on March 3I, r950, had reached a figure of just over $£_{39}$ millions. Future reports will show a much lower profit ratio since when benefit rates were increased substantially in 1952, the sole increase in contributions was an extra $\mathrm{Id}$. a week on the employer's contribution for insured adult men. The low expense ratio clearly proves the advantages of an all-embracing compulsory insurance scheme. Employers in the year covered by the report contributed just over $f_{0} \times 5$ millions to the Industrial Injuries Fund which may be compared with a total wages and salaries bill of 66,970 millions, the cost of compulsory insurance against industrial injuries to the employers being thus only a little over .2 of one per cent of their payments on account of wages and salaries. CMD. No. 8203. The surplus of the Industrial Injuries Fund for the year ended March 3I, I95I amounted to $f_{0} \times 9,940,000$. The expense ratio rose in this year to 7.2 per cent and payments to insured persons absorbed 38.6 per cent of the total receipts of the Fund. The amount of the Fund stood on March 31 , I95I at $f_{59}$, I05,000. (CMD. No. 8635 ).

202* The abolition of the principle of "alternative remedies" scems to have led to an increase in common law claims against employers. The chairman of the London and Lancashire Insurance Co. stated last year that whereas his company dealt with 68 workmen's common law claims in 1947, the number of such claims in I95I was 533. He forecast that premium rates would have to be substantially increased if this tendency were to continue. The (London) Times (Annual Financial and Commercial Review), Oct. I3, r952, p. I, col. 2.

${ }_{103}$ Total number of accidents reported to the Ministry of Labour (REPORT OF THE CHIEF INSPECTOR OF FACTORIES FOR 1950, CMD. No. 8445 at 227, App. iv (I952)):

$\begin{array}{lccc} & \text { Non-fatal Accidents } & \text { FatAI ACcidents } & \text { Total } \\ 1939 & 192,371 & 1,104 & 193,475 \\ 1950 & 192,260 & 799 & 193,059\end{array}$

I04 Cf. the speech of Lord Beveridge (then Sir William Beveridge, M. P.) in the House of Commons on Nov. 3 , I944. 404 H. C. DEB. II29 (5th ser. 1944). 
and, where contributions rates were also altered, new stamp values had to be printed. It stands to reason that we cannot go through this process once every year. If prices and incomes go on rising, it may become necessary to fix contributions as percentages of income so as to give the revenue the necessary buoyancy in a period of inflation. Benefits could then be adjusted easier in sympathy with some cost-of-living index. Such a change would, of course, run counter to Beveridge's assumption of a "flat rate of contribution." ${ }^{165}$ If that principle were, in fact, to be abandoned, the question might well be asked whether it was worth while to retain the fiction of an insurance scheme at all, or whether it would not better to merge contributions into the general revenue of the Exchequer and finance the scheme out of the income tax. ${ }^{100}$ But this is another story altogether.

IV

\section{General Conclusions}

The law relating to employers' liability is a subdivision of the law of tort and its development is therefore subject to much the same influences as have been observed for the latter. Not all of us may agree with Professor Friedmann when he says: ${ }^{167}$

The ... main function of the law of tort is the reasonable adjustment of economic risks in a capitalist ... society and not the expression of certain absolute moral principles.

We must, however, grant him that the law of employers' liability can be properly understood on this functional basis alone.

In a recent work, Dean Roscoe Pound has traced the law of employers' liability through five stages of historical development. ${ }^{168}$ According to him, employers' liability rested successively on:

r. The simple idea of causation (i.e., the vengeance principle);

2. the idea of fault (i.e., the moral principle);

3. the idea of control over dangerous activities;

4. the insurance principle (i.e., liability should rest with those best able to pass on the loss to the general public); and

5. the principle of greater ability to bear the loss sustained.

Of these five stages we are here not concerned with the first, which represents an early outlook, and the last which hardly deserves to be called a special stage in legal history. ${ }^{169}$ The existence of the remaining three stages may be easily proved in English law. Of course, as happens so often, all three ideas existed and still

${ }^{205}$ BEVERIDGE REPORT, CMD. No. 6404 at 12I, par. 305.

${ }^{100}$ The best argument in favour of this solution may be found in A. T. PEAcock, TrE Economics of Nattonal Insurance (1952). Cf. also Lady Rhys Williams, Taxation and Incentive (1953). (1948).

${ }_{107}$ W. Friedmann, Law and Social Change in Contemporary Brttain 97 (1951).

${ }^{208}$ JUSTICE ACCORDING TO LAW TO-IT (195X).

${ }^{100}$ It would be better to look upon it as an attitude guiding judges and juries in dealing with cases of industrial injuries. 
exist at the same time. What matters is which idea predominates at any one time and represents the epitome of contemporary legal thinking. ${ }^{\mathbf{1 7 0}}$

Roughly speaking, the heyday of the fault idea ended in 1880 . It was succeeded by the control idea ${ }^{171}$ which, in turn, in the I930's gave way to the insurance principle. Thomas Beven stated that the master-servant relationship had changed from status to contract and from contract to state regulation. ${ }^{172}$ This is not true, for modern law at least, as contract in this field preceded the rule of status. At common law, i.e., prior to the Employers' Liability Act, I880, the injured workman was able to claim damages not qua workman, but as a person injured through the negligence of another. The doctrine of common employment itself was only another aspect of the prevailing contract fetish. ${ }^{\mathbf{1 7 3}}$

The Employers' Liability Act, I880, represented the first breach in this principle when the employer was held responsible for the negligence of certain workmen exercising control over the plaintiff. This was followed by the passing of the Factories and Mines Acts which made the employer specifically responsible for the safety of premises under his control and the same idea invaded also common law via an extension of the employer's common law duties for the safety of his servants.

The date of commencement of our third stage is not easily fixed. Some might place it as early as 1897 when the first Workmen's Compensation Act was passed. This would be wrong as the 1897 Act was an experimental measure, ${ }^{174}$ probably much in advance of contemporary thought. ${ }^{175}$ The passing of the Act had been forced on unwilling politicians by sheer economic necessity. The employer-servant relationship had become weakened by the growth of large industrial concerns and the common law rules regarding negligence which might have been appropriate for the individual employer were not appropriate for the impersonal companyemployer. ${ }^{176}$ Once it had become accepted that it was socially expedient to distribute throughout the community the financial risks of industrial employment, the insurance principle was with us, ${ }^{177}$ though it took some time before it was given legislative sanction.

The developments which, after I88o, led to the breakup of the fault principle in the field of employers' liability may be summarized as follows: $:^{178}$

I. The common law duties of employers to workmen were extended. ${ }^{179}$

${ }^{270}$ Wright, The Law of Torts, 1923-1947, 26 CAN. B. REv. 46, 47 (1948).

${ }^{171}$ This idea was not unknown to earlier lawyers. The Select Committee on Railway Labourers, reporting in 1846 , recommended that railway employers should be made to pay compensation to their servants for accidents sustained at work as this would place responsibility on those "who have the greatest power to prevent the injury and the greatest means to repair it." Quoted by Robson, Industrial Relations and the State, I PoL. Q. $5 \mathrm{II}, 5 \mathrm{~T} 2$ (1930).

${ }^{172}$ 'The Law of Employers' Liability and Workmen's Compensation 3 (4th ed. 1909).

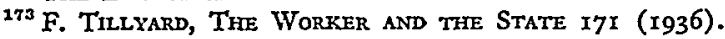

174 Id. at 26.

${ }^{176} \mathrm{It}$ was opposed by Liberals as unduly burdensome to employers and restrictive of liberty. I WrusoN AND LEVY, op. cit. stipra note 82 , at xiv.

${ }^{170} \mathrm{Id}$. at 57 .

177 A. A. Ehrenzweig, Negligence Without Fault 3 (I95T).

${ }^{178}$ Friedmann, op. cit. supra note 167 , at 84 ff.

${ }^{170}$ E.g., Wilsons and Clyde Coal Co., Ltd. v. English, [1938] A. C. 57. 
2. A restrictive interpretation was placed on most employers' defences. ${ }^{180}$

3. Further duties were imposed on employers by statute.

4. The Workmen's Compensation Acts were interpreted in a more liberal fashion. ${ }^{181}$

A reaction had to set in some time. Public opinion always appears to be in favor of the underdog ${ }^{182}$ and while in the last century the workman occupied this position, today, with increased social legislation and with strong trade unions, the employer is often more deserving of sympathy. The courts had shown the way towards an interpretation of the law more favorable to workmen; ${ }^{183}$. now they are to be found leading the retreat. ${ }^{184}$ This is understandable, since with a universal social insurance scheme the need to make the employer the unpaid insurer of the safety of his workmen has ceased.

- This modern trend has shown itself in a number of ways.

.. I. Liability based on fault has been reaffirmed in the interpretation of the Factories Acts by emphasizing the principle of foreseeability. ${ }^{185}$ A recommendation to introduce the principle of reasonable practicability into the Factories Acts has also been made by the Monckton Committee ${ }^{186}$ but has not been acted upon so far.

2. Courts have come to realize that many of the legal safeguards for workmen may be difficult to apply under modern economic conditions. Thus, in Latimer $v$. A:E.C. $L t d .^{187}$ the plaintiff had been injured when slipping on a damp floor at work after the premises had been flooded by an exceptional rainfall. He claimed damages for, among others, breach of the employers' duty at common law to provide safe premises. The trial judge having decided in the plaintiff's favor, the employers appealed. The appeal succeeded and in his judgment Singleton, L. J., referred to the absence of questions as to the economic consequences of a temporary closure of the factory, which would have been the only effective alternative to the employment of the plaintiff in dangerous circumstances. ${ }^{188}$

3. A further extension of compulsory state insurance at the expense of private in-

${ }^{180}$ (a) Volenti non fit injuria. Cf. Smith v. Baker \& Sons, [1891] A. C. 325; (b) Common Employment Cf. Radcliffe v. Ribble Motor Services, Ltd., [1938] I All E. R. 7x.

${ }^{181} \mathrm{Cf}$. the interpretation given to $\$ 29(\mathrm{I})$ concerning the workman's right of clection.

${ }^{182}$ For the reactions of the courts to this tendency, consult Friedmann, Social Sectrity and Some Recent Developments in the Common Law, 21 CaN. B. Rev. 369, 379 (1943).

${ }^{183}$ Cf. Friedmann, Statute Law and Its Interpretation in the Modern State, 26 CAN. B. Rev. 1277 f. (1948).

${ }_{184}$ Lawyers with socialist learnings view this trend wth obvious dislike, e.g., W. Friedmann's revicw of C. K. Allen, LaW in the Making (5th ed. 195I), in 15 Mod. L. Rev. 386, 389 (1952): "From the early 30 's to the middle 40's the House of Lords exercised a decisive influence on the adaptation of many branches of the law to new social needs. The majority of its members then believed in the common law as a growing organism which had to develop side by side with the action of the legislator. The philosophy of the present House of Lords is that of emphasizing traditional categories, however meaningless in modern times, and of refusing to use the many ways of creative development . . . for the rationalisation of law." Note also the same author's view in Law and Socinl. Change in Contemporanx BRITAIN 74 (I95I).

${ }^{185}$ E.g., Burns v. Terry, [195I] I T. L. R. 539.

186 Final Report of the Departasental Committee on Alternative Remedies, Cadd. No, 6860 at 35 , par. 82 (1946).

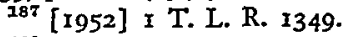

${ }^{188}$ Id. at 1354 . 
surance has been opposed as the latter still provides a continuing guarantee of the maintenance of safety precautions. ${ }^{189}$ The insurance company's agent is supposed to be acting as an unpaid factory inspector.

It appears then that fears which have been expressed that social insurance legislation would unduly weight the scales in the employees' favor, have been groundless. Our flexible common law system has restored the balance between an "injured's law" and an "injurer's law"190 without undue difficulty. The insurance principle, as distinct from the issue of compulsory state insurance, has long ago become part and parcel of the common law. The new legislation has thus led to administrative changes, it has replaced perhaps the immediate paymaster ${ }^{191}$ of the injured workman, but the fundamental change in outlook has taken place long ago.

189 Friedmand, Law and Socral Change in Contemporary Britain roo (195I). This is perhaps a questionable argument.

${ }^{100}$ Ehrenzweig, op. cit. supra note 177 , at 9 .

191 The ultimate paymaster must always be the general public, whether as consumers, as taxpayers, or as contributors to a compulsory insurance scheme. 